\title{
Dependence and Commitment: Main Determinants of Negotiation between Suppliers and Retailers
}

\author{
Mbarek Rahmoun (Corresponding author) \\ Management, Graduate School of Business of Tunis \\ 1141 Bir Mchergua, Tunisie \\ E-mail: mbarek.rahmoun@tunisietelecom.tn \\ Mohsen Debabi \\ Professor, Graduate School of Business of Tunis \\ 118 av Habib Bourguiba 2060 la goulette, Tunisie \\ E-mail: debabi_mmg@yahoo.fr
}

Received: March 19, 2012

Accepted: April 11, 2012 Published: June 1, 2012

doi:10.5539/ijms.v4n3p100

URL: http://dx.doi.org/10.5539/ijms.v4n3p100

\begin{abstract}
The aim of this paper is to attest for the relationship between producers' and retailers' dependence and commitment and the conduct of integrative negotiation. Principal Component Analysis (PCA) is a multivariate analysis method part of a group of multidimensional descriptive methods called factorial techniques. The results of a PCA analysis point to the unidimensionality of the two constructs of dependence and commitment. The results of a dyadic analysis of a sample of producers and retailers point to significant and positive relationship between dependence and commitment and the conduct of integrative negotiation. The regression estimates clearly support the fact that dependence and commitment have significant and positive impacts on the conduct of integrative negotiation.
\end{abstract}

Keywords: Retailing, Integrative negotiation, Trust, Dependence, Commitment, Cooperation, Distribution channel

\section{Introduction}

Retailing evolves under numerous changes affecting the sociological, economic, legislative and technological environments which affect in their turn all strategic decisions on the distribution channels (Filser, 1997; Paché, 1997). Indeed, these changes have seriously affected the relationship between producers and retailers (Filser, 1997; Sezen and Yilmaz, 2007), mainly at the level of power relationship between these protagonists. Parallel to conflicts, the exchange relationship between industry and business covers henceforth a number of cooperation areas more or less critical.

Within the new economic context, retailing incessantly evolves and takes channels more and more complex. Examining this evolution during the last twenty years, we note that retailers have gained more power while producers have lost most of it (Lendrevie and Lindon, 1997; Corsten and Kumar, 2005).

It is then important to determine a strategy that consists in unifying suppliers', wholesalers' and retailers' efforts in view of offering consumers a better service, of satisfying their needs and of improving the quality/price axiom. Synergy between these different components allows for developing and updating business practices in a way to make them more efficient in terms of time and money (Chung et al, 2006).

Marketing literature on distribution channels has often dealt with the issue from a conflict point of view (Filser, 1989; Morgan et Hunt, 1994; Etgar 1979; Allerheiligen, 1996) while a cooperative approach has been neglected (Morgan et Hunt, 1994). However, some authors are cognizant that distribution channels' agents could, by cooperating, maximise on benefits of each party and minimise conflicts and equally share profits (Axelrod, 1984).

Since the beginning of the 1980s, perception of the retailer's role has changed. Consumers are aware that mass distribution is an "ally" able of offering reasonably-priced products with an advantage of a satisfying quality. 
Three reasons explain this new attitude towards distribution (Lendrevie and Lindon, 1997): profits made from a war of prices, developments of brands and advertising. This new distribution relates also to the different challenges governing the sharing of power between clients and suppliers as the producer's marketing strategy lost its appeal in favour of the retailer who often requires brands that serve their retail strategy.

Because of these different factors, there appeared successive conflicts between producers and retailers (Lendrevie and Lindon, 1997; Bergès-Sennout and Caprice, 2003). Consequently, the relationships are conflict-based as each party seeks to dominate the other.

Our study aims at highlighting the importance of dependence and commitment and particularly the roles that determine a cooperative negotiation-based relationship between producers and retailers. Integrative negotiation has been generally described by researchers as a process known by a series of explanatory variables, more or less determinant, in line with its aim and implications within negotiation. Indeed, we may consider negotiation as a complex exercise with several determinants that jointly condition its conduct and results (Ferrier, 2010; Barth Isabelle and Bobot Lionel , 2011).

\section{The Theoretical Background of the Study}

\subsection{Integrative Negotiation}

Negotiations, as form of decision-making, take place when there are no decision-making rules, no authority and no fixed prices for the goods or services (W. Zartman, 2004). Negotiation dominates more and more daily concerns, establishing in the way more and more relational modalities based on contracts where negotiation skills became essential (Barth Isabelle and Bobot Lionel, 2011)

The literature showed that there are many trends studying negotiation and examining transactions between producers and retailers while theory of the nature and typology of negotiation between these two agents remains less studied (Rosenberg and Stern, 1971; Luch, 1976; Gaski, 1984; Pras, 1991; Angelmar, 1992; Filser, 1999; Debabi, 2002). The lietratur on negotiation devotes an important space to the nature of the relationship between seller and buyer (Anderson and Weitz, 1989; Bagozzi, 1975; Bazerman and Lewicki, 1985; Dwyer and al., 1987; Evans and Beltramini, 1987; Perdue, 1985; Walker, 1985).

Negotiation is seen in terms of either conflict resolution or cooperation (Macquin, 1995). For W. Zartman (1976), negotiation is primarily a transformation of values. there is no pre-defined rules for negotiation between producer and retailer. However, the intervening agents tend to favour their own interests. Integrative negotiation (Note 1), more and more recommended for the two parties, is creative, reconciling, open and sincere (Debabi, 2000).

Whatever its scope, any negotiation requires four essential inter-acting elements. The purpose of negotiation varies according to the area of intervention which may be qualitative or quantitative. Moreover, doesn't it depend on the negotiator's subjectivity? Likewise, we need to determine its context of application. Indeed, the purpose belongs to that context. This latter includes political and economic conditions. Circumstances like time and climate are contextual dimensions which give a sense of structure to the relationship between producers and retailers. Furthermore, the challenges are implicit but crucial elements in any negotiation. Indeed, these relate to the set of interests, concerns, needs, expectations, constraints and risks felt by negotiators (Dupont, 1990).

The outcomes determine the purpose of negotiation. They reveal the degree of interest each party devote to negotiation and determine protagonists' motivation levels. Moreover, when negotiators favour a power-based strategy, a power relationship is said to prevail the negotiation. C. Dupont (1990) defines it as a dependence degree in which one actor corners the other. The more this dependence is big, the more the power relationship inclines towards the actor who creates it. Power relationships are sometimes balanced and sometimes unbalanced. Studying power is very crucial given the effect it has on the negotiation process. Ramsay (1996) paid a great interest to the notion of power and its effects. Some authors even consider it as a central element in their studies (G. karras, 1986; J. Rojot, 1994). Negotiators maintain relational dynamics that may be decisive in a negotiation. This relationship results from the interconnections between negotiators' behaviour.

\subsection{Dependence between Partners}

R. M. Emerson (1962) defines this concept as follows: "dependence of an agent A to an agent B is directly proportional to B, and inversely proportional to the possibility of A to reach these objectives without B". In the same line of thinking, the author adds that power of agent A over agent B "is the sum of resistances of A who might be potentially overcome by B".

To understand power relationships within distribution channels, several authors treated the concept of 
dependence (J. Beier et L. W. Stern (1969); G. L. Frazier et J. O. Summers (1984); R. F. Dwyer et al. (1987). These authors particularly insisted on interdependence or possible reciprocity. For P. Louart (1999), this notion of interdependence is "useful to understand the prerequisites of alliances, partners and firms' networks".

M. Weber (1978) notes that "power is a property of social relationships and not an attribute of an actor". This is not often perceived within the relationship between $\mathrm{A}$ and $\mathrm{B}$, where it is about power used by some practitioners. This is true if B's requirements contrast with A's. In this context, A resists and B seeks to overcome such resistance, hence power may be revealed. This definition defines a real dependence relationship where power may or may not be revealed. However, not observing power features implies in no way its absence. In these terms a link may be created with the concept of power; dependence of one partner is the basis of the other's power in as much as partner A relies on B's intervention to reach his/her objectives. A is then said to dependent to B.

Dependence is also analysable using the resources model whose proponents treat its consequences in terms of uncertainty and its impact on the choice of the appropriate organisations strategies.

In marketing, resources dependence theory considers relationships between distribution agents as based on acquiring or exchanging these resources. S. S. Andaleeb (1995) confirms this hypothesis placing dependence relationships within the distribution channel. Indeed, dependence sums up the relationships in which a firm needs the resources of another firm to reach its objective and to survive. R. M. Emerson (1962), G. L. Frazier (1983), S. H. Kale (1986) and S. S. Andaleeb $(1995,1996)$ almost agree on this latter thesis. This is seen in the relationships between manufacturers and mass distribution where such dependence form is linked to the product referencing policy within large-scale and small-scale retailing.

Other authors, like W. Alderson, (1965); D. F. Dixon I. F. Wilkinson, (1986) consider the very interdependence between partners can be a source of conflict or/and cooperation. This dynamic perspective paves the way to a conception of a power relationship once a partner looks for the other to operate and reach their objectives.

This conception of power-dependence relationships contributes to understanding the intrinsic context of exchanges between parties at all levels of the channel in an interdependent fashion. It enriches power dynamics. This latter is defined as a function of dependence or interdependence of a party to another. This thesis is long adopted by L. W. Stern and J. Heskett (1969); D. Wilemon (1972); P. R. Dickson (1983); E. Anderson et al. (1987).

According to F. J. Beier and L. W. Stern (1969), it is clear that the interdependence process is very important for a dynamic buyer-seller relationship as there is no one power holder in the process.

A. I. El-Ansary and R. A. Robicheaux (1974) approve of this perspective and underline that in dynamic relationships within a distribution channel "each member holds power over different areas, executing I different ways". A producer or a retailer may request the other party to fulfil their reciprocal commitments (logistics, merchandising). Then power should be defined and measured in terms of dyadic relationships; this is not a unilateral process, it groups together flows of reciprocal or mutual influences.

Moreover, reciprocity in power-dependence relationships leads us to raise the equality or inequality issue within that relationship. In this study, it is between the producer and retailer.

Concerning contexts, the most frequent in distribution channels or where power is ill balanced, parties work hard to stabilise the relationship by modifying power-dependence structure which is stabilised when each party (producer or retailer) align together to reach their mutual objectives or when there are mutual rights and commitments.

Likewise, power leads to counter-power in the same way dependence leads to counter-dependence or to a reciprocal dependence. According to R. M. Emerson (1962), a dependent party tries to counter-balance this dependence by diminishing it and/or by trying to create an interdependence that makes the other party dependent in turn.

\subsubsection{Theoretical Approaches to Dependence}

In marketing, we point to some approaches to dependence. We distinguish three trends. Firstly, the sales and profits approach which is developed by A. I. El-Ansary and L. W. Stern (1972). Sales and profits are two extremely important objectives. According to this approach, the more sales and profits are higher, the more the source firm is independent.

Secondly, the performance approach developed by G. L. Frazier (1983) and used in the marketing literature on distribution channels to explain grounds of the intermediary's dependence. G. L. Frazier (1983) maintains that 
the more the source firm's performance level is high, the more the target's motivation to maintain the exchange relationship is high. The two firms agree to accomplish some tasks and assume some responsibilities.

Thirdly, the approach of specific assets and compensation investment developed by J. B. Heide and G. John (1988), focuses on analysing transaction costs of the dependence theory.

\subsubsection{Interaction between Interdependence and Power}

Power is presented as a key concept of analysing the distribution channel. The basics of all works on power, cooperation and conflict are incontestably presented in the typology developed by J. French and B. Raven (1959). Within the distribution channel, behavioural studies are devoted to explain power relationships between the channel's actors. Equally, power is object of several studies which tried to determine its nature and the way of obtaining it, use and management. Several studies on distribution channels like those of F. Hegel (1822) and E. Kant (1784) focused on power and conflict. For Kant, antagonism is basic and is the fruit of 'men's unsociable sociability".

The significant contribution to cooperation and conflict resides in its execution (Remili and Carrier 2006). Each one of us needs to unite with others. Men by definition cannot live in isolation nor retreat from their own breed. Their ambitions to work and be satisfied are even found in their desire to live in a society governed by a control relationship and profit-making through cooperation. This latter is an essential element for a better life and sharing of interests between protagonists.

As for power development between protagonists within a distribution channel, we point out that power is a crucial element that manages the relationship between parties. It is equally a means and an end for the micro-society that the distribution channel represents. W. Alderson (1955) maintains that "products are channelled by a power structure and not a neutral means that the distribution channel term suggests. Transactions between two operating systems often imply the two factors of economic value and power equilibrium".

\subsection{Commitment during Cooperation}

In order to last and function well, cooperation requires partners' mutual commitment. R. M. Morgan and S. D. Hunt (1994) consider commitment as a key mediating variable in their model of relational marketing and define it as the customer's willingness to make the necessary efforts to maintain a long relationship that he/she judges important.

The literature cites two main definitions of commitment. The first, to which R. M. Morgan and S. D. Hunt (1994) refer to, is purely cognitive. It refers to explicit commitment which is defined as the willingness to maintain a valuable relationship that will last and be sustained during time. The second definition reports rather to behaviourist tones and relate to the work of C. Kiesler (1971). It refers to implicit commitment, i.e. the customers' knowledge of their own purchasing behaviour towards a partner. This definition, retaken by R. F. Dwyer and S. Oh, (1987), E. Anderson and B. A. Weitz (1992), has two dimensions: an economic and a psychological one. The authors define commitment as an implicit or explicit guarantee for the continuation of the relationship between the two parties. According to them, commitment assumes customers' willingness to make short-term sacrifices in order to achieve important benefits in the long-run.

The literature devoted to the subject considers commitment as a key indicator of relational quality (Buch and Wilson, 1976; Scheer and Stern, 1992). C. Moorman et al. (1992) consider commitment as "a continued desire to maintain a valuable relationship". Economics-wise, the consumer is committed because he/she cannot redeploy specific assets already deployed for the exchange like entry rights and accumulated faithfulness points or because seeking a new supplier involves change costs. Psychology-wise, implicit commitment is a justification of purchasing decisions taken freely the questioning of which would involves for the consumer psychological costs. Retailers can find themselves in a situation similar to that of the consumer. Indeed, once committed, retailers cannot redeploy employed specific assets as looking for a new producer signifies change costs and unease.

This rationalisation leads to stabilising beliefs and behaviour. Commitment is then a residue of an exchange between partners bound by their strong desire to maintain stability and continuity of the exchange. It translates the two partners' long-term orientation. Accordingly, it is viewed as the probability of continuity of the exchange in time.

Relationships between retailers and suppliers are founded on mutual commitments which locate actors within a long-term partnerships characterized by a dyadic (or a network-based) component. From a cognitive perspective, commitment is the desire to maintain an appreciated relationship (Moorman et al., 1992), acting like an implicit or explicit promise to continue the exchange relationship between partners (Dwyer et al., 1990), or a belief that 
makes the importance of the relationship a justification for deploying the maximum of efforts to maintain it. R. M. Morgan and S. D. Hunt, (1995) and G. T. Gundlach et al., (1995) define commitment as the partners' exchange willingness to deploy an effort for the sake of the relationship and suggest a future perspective where firms try to build a durable relationship even in case of unexpected problems.

\subsubsection{Components of Commitments}

The notions of solidarity and cohesion are very close to commitment (G. T. Gundlach et al. 1995). This notion involves three components:

The instrumental component or "input": instrumentally speaking, commitment is an act computable through an input differently initiated and closed, credibility, specific investments, the specific resources allocated to the relationship. These inputs are difficult to redeploy in another relationship. Other reciprocal inputs assume durable and stable relationships as well as reciprocal trust aligning thus partners' encouragement mechanisms.

The attitudinal component: it relates to affective, psychologically-based, identity-oriented, affiliation-favoured and value-enhancing commitment. It operates on the intention to develop and maintain a stable long-term relationship.

The time component: It is the essence of commitment. It highlights only the long-term orientation. The inputs directly result in long-term commitment. The involved partners no longer seek relationships or alternative rewards. Long-term relationships cut on learning costs, benefit from experience, and require simpler, more flexible and reductive of ambiguity administrative tools and management systems.

The result would be that partners having strong affective commitment with some suppliers would willingly maintain their relationship, while partners having a moral commitment tend to execute it as an obligation. Still, partners with strong commitment tend to execute it by necessity. In this line of thinking, commitment is all together a desire, an obligation and a need.

\subsubsection{Structure of Commitment}

Consumers' willingness to engage into a purchasing relationship depends on more their cognitive ability to build a trust-based relationship relative to a brand or a partner than on their previous purchasing behaviour.

G. T. Gundlach et al. (1995) specify two dimensions for commitment structure: credibility and proportionality.

- Credibility is commitments intensity degree of partners. Those who are less credible create confusing motivations with a lack of a strong normative culture and weak long-term commitments.

- Proportionality or reciprocity implies that balanced commitments provoke partnership while ill-balanced commitments lead to contradictory outcomes.

Commitment assumes a long-term adoption of a perspective. This latter is based on exchange stability in order for partners to achieve long-term benefits.

In their relational marketing model, R. M. Morgan and S. D. Hunt (1994) maintain three factors and three consequences for commitments. Factors behind commitment are the commonly-shared values, benefits of the relationship and disruption costs of the relationship, while the consequences are consent, propensity of ending the relationship and cooperation.

By commitment, producers reach easily market information to develop and launch new products and reduce thus retailers' interests in promoting competitors' brands. Likewise, retailers have a higher access rate to products demanded by their customers and more chance to differentiate themselves from other retailers. Suppliers and consumers engage themselves because they find their behaviour a certainty.

According to J. Frisou (2000) two distinct models may explain the position of consumers' durable commitment in an exchange relationship. For the first, the consumer is committed because hi/her trust in the partner dissipate his/her uncertainty. For the second, by committing him/herself the consumer assumes uncertainty as he/she feels already committed to his/her previous purchasing behaviour.

\section{The Research Hypotheses}

Dependence is often treated as a factor behind cooperation (Heide and John, 1990; Skinner et al., 1992). The theories studying inter-organisational cooperation underlined the impact of interdependence between partners: partners engage into negotiations once they are dependent to each other and share the same interests (Pfeffer and Salancik, 1978; Williamson, 1985). Integrative negotiation is equally understood as a willingness to increase resources aimed at maintaining a fair and a rewarding compromise that insures positive results (Othman Bartos, 1974). 
Our research hypothesis on dependence is reformulated in line with the work of S. J. Skinner et al., (1992), R. F. Lusch and J. R. Brown (1996):

H1 Dependence between producer and retailer positively affects the conduct of integrative negotiation.

We assume as well the presence of a causality relationship between commitment and conducting integrative negotiation. Then our second research hypothesis runs as follows:

$\mathrm{H} 2$ Commitment between producer and retailer positively affects the conduct of integrative negotiation.

\section{The Methodology}

During scale purification phase, using a questionnaire 53 producers have been interviewed on dependence dimensions, commitment and the conduct of integrative negotiation. We were able to measure the dimension of integrative negotiation using the items retained for its measurement. The results processed by a Principal Component Analysis technique eliminated 3 ill-represented items and consequently we retained 6 over 9 items. In a confirmatory phase, a sample of 253 producers has been interviewed to test this hypothesis. We retained a stratified sampling procedure as the list of producers is available.

To test the hypothesis against retailers' perception, we set a sample of 53 managers of food retailing whose names were given by their suppliers.

\subsection{Integrative Negotiation Measurement Scale}

The producer-retailer relationship has known some change during recent years mainly with trade marketing and category management development. This cooperative management perspective should change negotiation between producers and retailers to gear them towards an integrative dimension. This relationship tends consequently to save, consolidate, even reinforce the quality of the relationship between partners. It could lead to modifying specific objectives of their respective owners to have strong and durable relationships whose objective to consolidate common interests. Indeed, partners should believe in an evolution towards a fair and mutually beneficial partnership.

Several authors have attempted to introduce some behavioural variables in their models of producer-retailer relationships such as power sources model (French and Raven, 1959) modified by Hunt and Nevin (1974). Stern and El Ansary (1992) consider this cooperation as crucial if consumers are to be satisfied.

To measure the cooperative dimension, Graham (1986) refers back to a five-point semantic scale to evaluate negotiators' perception. In a study on international business negotiations tactics, Fraser (2005) used a Lickert-type scale. The same scale is used in our study to measure a nine-item integrative negotiation between producers and retailers.

It is very important to examine cooperative behaviour during exchange. This behaviour is considered by many authors (M. Monzano, 1997; L. W. Stern and A. I. El-Ansary, 1977) as components necessary to relationships within the distribution channel so as to satisfy and meet end-consumers' needs (A. I. El-Ansary, 1992).

The Principal Component Analysis (PCA) is a multivariate analysis method part of a group of multidimensional descriptive methods called factorial techniques. This procedure rests on an exploratory phase centred on studying a factorial structure using a principal component analysis meant to be an exploratory technique to summarize relationships between variables using the most reduced factor structure. PCA is a technique used to reduce dimensions. It allows for extracting data from a multidimensional scatter plot.

The PCA conducted on this 9-item scale identified two factors with the following respective loadings 3,395 and 1,540. These two factors explain $54,839 \%$ of total variance. We then opted for a preliminary analysis to eliminate ill-represented items with low factorial loadings. Thus, items Neg 7, Neg 8 and Neg 9 have been ultimately eliminated and 6 items are retained.

A second PCA is conducted and resulted in one factor explaining 50\% of total variance. The results show that the items of integrative negotiation explain better this dimension and allowed us to retain the unidimensionality of the scale.

\subsection{Dependence Measurement Scale}

Dependence has been subject of several studies by different approaches. Table 2 below summarises this panoply of research.

To measure dependence between retailer and supplier, we used the items developed by C. Bozzo (2000) and K. Machat (2003) and the works of S. Ganesan (1994) and R. M. Morgan (1991) on suppliers-retailers relationships. 
The reliability analysis of the dependence scale shows the validity of the 4-item construct. Cronbach's Alpha is very satisfying $(\alpha \approx 0,794)$.

Commitment refers back to the willingness to maintain a relationship in the long-term and to make necessary sacrifices to reach that goal.

Commitment dimensions differ according to authors. R. F. Dwyer et al, (1987), for instance, measured the concept in three dimensions: the input, durability and growth dimensions.

To measure commitment, E. Anderson and B. A. Weitz (1992) used items reflecting behaviour, attitudes and intentions. R. M. Morgan and S. D. Hunt (1994) retained two dimensions to measure commitment; importance of relationship for practitioners and their intentions to maintain the relationship.

J. Frisou (2000) retains the two dimensions of explicit and implicit commitment while S. Ganesan (1994) retained the one dimension of loyalty intention.

The PCA allowed us to retain one factor with 5 items which explains $59,740 \%$ of total variance. Moreover, KMO and Bartlett's Sphericity tests confirm that the data is factorial (Hair et al., 1995), with a value equal to 2,987. These estimates show that 5 items equally contribute to the representation of commitment (Eng3, Eng2, Eng1, Eng6, Eng5).

Commitment presents good reliability estimates with an Alpha coefficient equal to 0,826 . The results confirm that commitment measurement scale is unidimensional. The items explain very well this dimension.

\section{Testing the Hypotheses}

\subsection{Testing Producers Perceptions}

This stage consists in testing significance of the relationship between dependence and commitment. The following table summarizes the results:

The results of the causality effect estimation are satisfactory. We point to the significance of the relationship between dependence and integrative negotiation conduct (computed $t=2,180$ and then superior to 1,96 ). We also point to the significance of the relationship between commitment and integrative negotiation conduct.

\subsection{Testing Retailers Perceptions}

A regression analysis has been conducted to examine the impact of dependence on integrative negotiation conduct. The following table summarises these results.

The obtained results show that dependence is a main determinant of integrative negotiation conduct (non-standardized regression coefficient $\mathrm{B}=0,351$ and the student test $=2,934$ ). The relationship between perceptions is a significant and positive one at the $5 \%$ level ( $t$ test significance $=0,004$ ) and consequently our hypothesis (dependence between producers and retailers positively affects integrative negotiation conduct) is retained. This analysis allows for underlining the positive influence that dependence has on integrative negotiation conduct according to the dyadic approach.

The obtained results show also that commitment is a main determinant of integrative negotiation conduct (non-standardized regression coefficient $\mathrm{B}=0,401$ and the student test $=3.426$ ). We note that retailers' commitment has a significant and positive impact on integrative negotiation conduct.

\section{Conclusions and Limitations of the Study}

The aim of this study is to examine the impact of dependence and commitment on integrative negotiation conduct within a business exchange between producers and retailers.

In this line of thinking, we studied power relationship between producers and retailers within the Tunisian context and the impact of this relationship on negotiation outcomes.

Marketing literature on distribution channels consider the relational aspect of exchange and its implications on exchange behaviour as an important point whose extent is worth studying. Indeed, dependence, trust, power, conflict and control play an important role in explaining the nature of the producer-retailer relationship. It is then important to examine cooperative behaviours within exchanges, considered by many authors as necessary components of a relationship within distribution channels and as a ground condition to satisfy consumers' end needs. To increase global efficiency of a vertical marketing system, it is important to follow a procedure that aims at researching several solutions whose objective is to find satisfying solutions that limit conflict. Indeed, cooperation is considered as the most constructive solution to the conflict.

Within a risky economic context which is changing rapidly and where competition and new technologies reign, 
cooperation and partnership agreements have known their peak. Cooperation between producers and retailers is becoming more and more a must. Building such cooperation is no longer a lucky strike, rather it is the fruit of so very close interests in front of a tense competition and an organised retailing, more and more powerful and concentrated. Seen from the dynamics of the negotiation process, the relationship between producers and retailers has often been perceived in conflict terms reflecting a desire to guarantee rather unilateral interests. However, interdependence of their activities normally should lead these parties to manage their aims differently.

Generally speaking, the relationship between two organisations is based on an exchange of resources, tangible or intangible and rare are the relationships that are based on mutual interdependence and equal power distribution. In most cases, there is what is known as power asymmetry where a firm depends on another (Remili and Carrier 2006).

Literature-wise, importance of integrative negotiation to develop and maintain exchange relationship is receiving more and more attention by marketers. Within research on negotiation, although the relationship between dependence and integrative negotiation is not monotonic, we may speculate that dependence and commitment make the negotiation more cooperative between partners.

Indeed, concentration of mass retailing led to increasing retailers' purchasing power which represents in its turn a genuine counter-power mechanism while negotiating with producers.

Our results allowed us to test the fact that producers and retailers equally perceive the impact of dependence and commitment on integrative negotiation conduct.

The main limitation of this study relates to the size of the two samples. For the producers, it was easy for us to interview a considerable number of people ( 253 individuals) in as much as retailers deal with hundreds of suppliers. However, for the retailers, only 53 individuals made the sample. This is due to the limited number of stores in Tunisia.

Future research may be conducted to examine the extent to which the nature of retailing format may have an impact on negotiations between producers and retailers.

\section{References}

Alderson, W. (1965). Dynamic Marketing Behavior. Homewood, Illinois, Richard D. Irwin, Inc.

Andaleeb, S. S. (1995). Dependence Relations and the Moderating Role of Trust: Implications BehavioralIntentiions in Marketing Channels. International Journal of Research in Marketing. http://dx.doi.org/10.1016/0167-8116(94)00020-O

Angelmar, R. (1992). Les Conflits dans les canaux de distribution. Encyclopédie de Management. Paris, Vuibert, janvier, tome 1.

Bagozzi, R. (1975). Marketing as Exchange. Journal of Marketing, 39 (October), 32-9. http://dx.doi.org/10.2307/1250593

Barth Isabelle \& Bobot Lionel. (2011). Négociations, 5-9.

Bazerman, M., \& Lewichk, R. (1985). Contemporary Research Directions in the Study of Negotiations. Journal of Occupational Behavior, 6.

Beier, F. J., \& Stern, L. W. (1969). Power in the Channel of Distribution. Distribution Channel: Behaviore Dimension. éd. L.W. Stern, Boston, Ma, Houghton Mifflin Co.

Bergès-Sennout, F., \& Caprice, S. (2003). Vertical Relations-Ships Between Manifacturies and Retailers: Determinants and Consequences of Buying. Intra- ESR, Toulouse.

Bozzo, C. (2000). Modélisation du omportement d'achat en milieu industriel: fidélité, rétention, inertie. Thèse en Sciences de gestion, Université d'Aix-Marseille.

Brown, J., Lusch, R., \& Muehlin, D. D. (1983). Conflict and Power-Dependence Relations in Retailer- Supplier Channels. Journal of retailing, 59(4), Winter.

Busch, P., \& Wilson, D. T. (1976). An experimental analysis of a salesman's expert and referent bases of social power in the buyer-seller dyad. Journal of Marketing Research, 13(1), 3. http://dx.doi.org/10.2307/3150896

Chung, J. E., Sternquist, B., \& Chen, Z. (2006). Retailer-buyer Supplier Relationships: The Japanese Differene. Journal of Retailing, 82, 4. http://dx.doi.org/10.1016/j.jretai.2006.08.008

Corsten, D., \& Kumar, N. (2005). Do Suppliers Benefit from Collaborative Relationships With Large Retailers? An Empirical Investigation of Efficient Consumer Response Adoption. Journal of Marketing, 69(3). 
http://dx.doi.org/10.1509/jmkg.69.3.80.66360

Debabi, M. (2000). Dimensions intégratives et distributives de la négociation entre producteurs et distributeurs. AFM.

Dickson, P. R. (1983). Retailer Portfolio Analysis and the Channel Dependence Matrix: New Techniques for understanding and managing the Channel. Journal of Marketing, 47(3). http://dx.doi.org/10.2307/1251195

Dixson, D. F., \& Wilkinson, I. F. (1986). Toward a Theory of Channel Structure. Research in Marketing Distribution Channels and Institutions, 8.

Dwyer, F. R., Schurr, P. H., \& OH, S. (1990). Developing Buyer-Seller Relationships. Journal of Marketing, $51(2)$.

Dwyer, R. F., \& OH, S. (1987). Output Sector Munificence Effects on the Internal Political Economy of Marketing Channels. Journal of Marketing Research, 20.

EL-Ansary A. I., \& Robicheaux, R. A. (1974). A Theory of Channel Control: Revisited. Journal of Marketing, $38(1)$.

El-Ansary, A. I. (1992). Marketing Channels (4th ed.). Englewood Cliffs, NJ: Prentice.

Evans, K., \& Beltramini, R. (1987). A Theoretical Model of Consumer Negotiated Pricing: An Orientation Perspective. Journal of Marketing, 51 (April).

Ferrier, O. (2010). Les tactiques de négociation: principes, risques, parades, contre-attaques et fondements psychologiques.

Filser, M. (1997). Évolutions et stratégies dans la distribution alimentaire: les apports des sciences de gestion, Actes du Colloque Grande Distribution Alimentaire, Montpellier, 22-23 mai, tome 1, SFER, Séries de notes et documents, 107.

Frazier, G. L. (1983). On the Measurement of Interfirm Power in Channels of Distribution. Journal of Marketing Research, 20.

Frazier, G. L., \& Summers, J.O. (1984). Interfirm Influence Strategies and Their Application Within distribution Channels. Journal of Marketing, 48.

Frazoer, G. L., Gill, J. D., \& Kale, S. H. (1989). Dealer Dependence Levels and Reciprocal Actions in a Channel of Distribution in a Developing Country. Journal of marketing, 53.

French, J. R. P., \& Raven, B. (1959). The Basis of Social Power, Studies in Social Power, éd. D. Cartwright, Ann Arbor, Mich., University of Michigan Institue Press for Social Research.

Gaski, J. F. (1984). Theory of Power and Conflict in Channels of Distribution. Journal of Marketing Research, 48.

Gundlach, G. T., \& Cadrotte, E. R. (1994). Exchange Interdependence and Interfirm Interaction, Research in a Simulated Channel Setting. Journal of Marketing Research, VXXXI.

Gundlach, G. T., Achrol, R. S., \& Mentzer, J. T. (1995). The Structure of Commitment in Exchange. Journal of Marketing, 59(1). http://dx.doi.org/10.2307/1252016

Heide, J. B., \& John, G. (1988). The Role of Dependence Balancing in Safeguarding Transacton-Specific Assets in Conventional Channels. Journal of Marketing, 52.

Heide, J. B., \& John, G. (1990). Alliance in Industrial Purchasing: The Determinants of Joint Actions in Buyer-Supplier Relationships. Journal of Marketing Research, XXVII.

Hunt, S. D., \& Nevin, J. R. (1974). Power in a Channel of Distribution: Source and consequence. Journal of Marketing Research, 11.

Kale, S. H. (1986). Dealer Perceptions of Manufacture Power and Influence Strategies in a Developing Country. Journal of Marketing Research, XXIII.

Karrass, G. (1986). Marché conclu, Edition Rivages/les Echos.

Kiesler, C. (1971). The Psychology of commitment: Experiments Linking Behavior to Beliefs. New York, Academic Press.

Kumar, N., Scheer, L. K., \& Steenkamp, J-B. E. M. (1995). The Effects of Supplier Fairness on Vulnerable Resellers. Journal of Marketing Research, 32, February. 
Lendrevie, J., \& Lindon, D. (1997). Mercator. Dalloz $5^{\text {ème }}$ édition.

Lourat, P. (1999). Dépendance /Domination. Encyclopédie de la Gestion et du Management, E.G.M. éd. R. Le duff, Paris, Dalloz.

Luch, R. F. (1976). Source of power: Their Impact on Intrachannel Conflict. Journal of Marketing Research, 13.

Lusch, R. F., \& Brown, J. R. (1996). Interdepency, Contracting, and Relational Behavior in Marketing Channels. Journal of Marketing, 25.

Machat, K. (2003). Apprentissage Marketing et Interaction Client-Fournisseur. Université Montplier II.

Manzano, M. (1997). Les relations coopératives entre les producteurs et les distributeurs de produits alimentaires et non alimentaires.

Marc Filser. (1989). Canaux de distribution. Paris, Vuilbert, collection Gestion.

Moorman, C., Deshpende, R., \& Zaltman, G. (1993). Relationships Between Providers and Users of Market Research: The Role of Personal Trust. Journal of Advertising Research, 8.

Moorman, C., Zaltman, G., \& Deshpande, R. (1992). Relationship Between Providers and Users of Market Research: The Dynamics of Trust Within and Between Organizations. Journal of Marketing Research, 24.

Morgan Robert Met Hunt shelby D. (1994). The Commitment-Trust Theory of Relationship Marketing. Journal of Marketing, 58(3).

Noordewier, T. G., John, G., \& Nevin, J. R. (1990). Performance Outocomes of Purchasing Arrangements in Industrial Buyer-Vendor Relationships. Journal of Marketing, October.

Paché, G. (1997). La logistique des détaillants français: une externalisation atypique? Actes du Colloque Grande Distribution Alimentaire, Montpellier, France, 22-23 mai, tome 1, SFER, Séries de notes et documents, n 107.

Perdue, B. (1985). A Model of Industrial Buyer-Seller Negociations. Advances in Consumer Research, 12, 252-5. E. Hirschman and M. Holbrook, eds. Ann Arbor, MI: Association for Consumer Research.

Pras, B. (1991). Stratégies génériques et de résistance dans les canaux de distribution: Commentaire et illusion. Recherche et Application Marketing, 6(2).

Ramsay. (1996). Power Measurement. European Journal of Purchasing and Supply Management, 2(3).

Remili, N., \& Carrier, S. (2006). Exploration du concept de dépendance commerciale dans un contexte de turbulence: le cas de l'industrie québécoise du vêtement, Actes de la conférence ASAC Banff.

Rojot, J. (1994). la négociation. Editions vuibert.

Rosenberg, L. J., \& Stern, L. W. (1971). Conflict Measurement in the Distribution Channel. Journal of Marketing Research, VIII.

Scheer, L. K., \& Stern, L. W. (1992). The Effect of Influence Type and Performance Outcomes on Attitude Toward the Influencer. Journal of Marketing Research, 29, 128-42. http://dx.doi.org/10.2307/3172498

Sezen, B., \& Yilmaz, C. (2007). Relative Effects of Dependence and Trust on Flexibility, Information Exchange, and Solidarity in Marketing Channels. The Journal of Business \& Industrial Marketing, 22(1). http://dx.doi.org/10.1108/08858620710722815

Skinner, S. J., \& Guiltinan, J. P. (1985). Perception of Channel Control. Journal of Retailing, 61(6), winter.

Skinner, S. J., Gassenheimer, J. B., \& Kelley, S. W. (1992). Cooperation Supplier-Dealer Relations. Journal of Retailing , 68(2).

Stern, L. W., \& El-Ansary, A. I. (1977). Marketing Channels. Englewod Cliffs, New Jearsay, Printice Hall.

Stern, L. W., \& Heskett, J. (1969). Conflict Management in Interorganizational Relations: A Conceptual Framework. Distribution Channels: Behavioral Dimensions, éd. L.W. Stern, Boston, Ma, Houghton Mifflin, Co.

Walker, O. C. (1985). Sales Management Theory and Practice: A State of the Art Rview. Marketing teleconference sponsored by American Marketing Association and Oklahoma State University (March).

Weber, M. (1978). Economy and Society. Berkeley, CA, University of California Press.

Wilemon, D. (1972). Power and Negotiation Strategies in Marketing Channels. Southern Journal of Business, février, 7.

Zartman, I. W. (1976). The 50 per cent solution. Anchor Books (New York). 


\section{Note}

Note 1. Integrative, in contrast to distributive, is used in the literature on negotiation by authors like Dupont (1982) and Lewick (1985). Integrative negotiation corresponds to cooperation-dominated negotiation and distributive negotiation corresponds to a conflict-dominated negotiation.

Table 1. Integrative negotiation items

\begin{tabular}{|l|l|}
\hline Neg1 & The parties negotiate flexibly to adjust their respective interests. \\
\hline Neg2 & The parties seek shared interests with a win-win perspective \\
\hline Neg3 & Integrative negotiation contributes to conflicts resolution. \\
\hline Neg4 & Today, we agree on the passage from distributive negotiation to integrative negotiation. \\
\hline Neg5 & Negotiation distinguishes itself by a constructive information exchange. \\
\hline Neg6 & The subject of negotiation is likely to be extended. \\
\hline Neg 7 & Integrative negotiations best guarantee good compromises. . \\
\hline Neg 8 & All clauses of the bid should be negotiable. \\
\hline Neg 9 & Imagine the maximum of exits to avoid a dead-end negotiation. \\
\hline
\end{tabular}

Table 2. Main measurement of dependence

\begin{tabular}{|c|c|}
\hline Authors & Variables \\
\hline El- Ansary and Stern (1972) & $\begin{array}{l}\text { Percentage of sales and profits made by the source. } \\
\text { Target commitment } \\
\text { Difficulty of replacing source. }\end{array}$ \\
\hline Frazier (1983) & Producer Performance \\
\hline Brown, Lusch and Mueling (1983) & $\begin{array}{l}\text {-satisfaction of intermediary in charge of selling producer's } \\
\text { items. } \\
\text {-difficulty of finding another supply alterative }\end{array}$ \\
\hline Anderson and Narus (1984) & $\begin{array}{l}\text { - results of the relationship } \\
\text {-results compared to competitors }\end{array}$ \\
\hline Skinner and Guiltinan (1985) & $\begin{array}{l}\text { - retailer satisfaction } \\
\text { - retailer's dependence to product range }\end{array}$ \\
\hline Kale (1986) & - sales and profits future expectations \\
\hline Heide and John (1988) & - substitution of commissions revenues \\
\hline Frazier, Gill and Kale (1989) & $\begin{array}{l}\text {-level of achieved sales and profits } \\
\text { - level of expected sales and profits }\end{array}$ \\
\hline Noordewer, John and Nevin (1990) & -2 propositions \\
\hline $\begin{array}{l}\text { Skinner, Gassenheimer and Kelly } \\
(1992)\end{array}$ & -16 propositions \\
\hline Ganesan (1994) & $\begin{array}{l}\text { - percentage of sales (1 item) } \\
\text { - supplier's importance degree (8 items) }\end{array}$ \\
\hline Heide (1994) & -4 propositions \\
\hline Gundlach and Cadotte (1994) & - percentage total gross margin derived from the partner \\
\hline Kumar, Scheer and Steenkamp (1995) & -3 propositions \\
\hline Lusch and Brown (1996) & -3 propositions \\
\hline Guibert (1999) & $\begin{array}{l}\text {-difficulty of terminating the relationship } \\
\text { - adaptation efforts } \\
\text { - dependence evaluation }\end{array}$ \\
\hline Batt (2000) & $\begin{array}{l}\text { - independence }(6 \text { items }) \\
\text {-availability of alternatives ( } 3 \text { items) } \\
\text {-comparaison of alternatives }(1 \text { items })\end{array}$ \\
\hline
\end{tabular}


Table 3. This study's supplier dependence scale

\begin{tabular}{|l|l|l|}
\hline & $\begin{array}{l}\text { Supplier Dependence: } \\
\text { 5-point Lickert Scale }\end{array}$ & Authors \\
\hline$>\quad$ Depd1 & $>\quad$ We could hardly replace this retailer by others. & $\begin{array}{l}\text { Ganesan (1994) } \\
\text { kurmar et al (1995) } \\
\text { Lusch and Brown (1996) } \\
\text { Bozzo (2000) } \\
\text { Machat(2003) }\end{array}$ \\
$>\quad$ Depd3 & $\begin{array}{l}\text { If we keep this retailer it is out of economic } \\
\text { necessity rather than willingness. } \\
\text { survival of our firm. }\end{array}$ & $\begin{array}{l}\text { Terminating this relationship threatens the } \\
>\quad \text { Our performance depends on this customer. }\end{array}$ \\
\hline Depd4 & $>\quad$ & \\
\hline
\end{tabular}

Table 4. Main commitment measurement scales

\begin{tabular}{|c|c|c|}
\hline Authors & Variables & Measurement Scale \\
\hline Anderson and Weitz (1992) & $\begin{array}{l}\text { - loyalty in its broadest sense } \\
\text { - expectation of relationship } \\
\text { continuity } \\
\text {-willingness to invest in the } \\
\text { relationship } \\
\text {-willingness to make short-term } \\
\text { sacrifices } \\
\text { - defence and patience behaviour }\end{array}$ & $\begin{array}{l}\text { 7-point scale } \\
1: \text { totally disagree } \\
7: \text { totally agree }\end{array}$ \\
\hline $\begin{array}{l}\text { Moorman, Deshpandé and } \\
\text { Zaltman (1992) }\end{array}$ & -3 propositions & 7-point scale \\
\hline Ganesan (1993) & $\begin{array}{l}\text { - long-term objectives } \\
\text {-long-term concessions } \\
\text {-long-term profitability }\end{array}$ & $\begin{array}{l}\text { 7-point scale } \\
1: \text { totally disagree } \\
7: \text { totally agree }\end{array}$ \\
\hline Morgan and Hunt (1994) & $\begin{array}{l}\text {-relationship importance } \\
\text {-intention to maintain the } \\
\text { relationship }\end{array}$ & 7-point scale \\
\hline Ganesan (1994) & $\begin{array}{l}\text { - long-term objectives } \\
\text {-long-term concessions } \\
\text {-long-term profitability }\end{array}$ & 7-point scale \\
\hline Mohr and Spekman (1994) & -3 propositions & -7-point scale \\
\hline $\begin{array}{l}\text { Patricia Gurviez and Michael } \\
\text { Korchia (2002) }\end{array}$ & -1 proposition & -7-point scale \\
\hline
\end{tabular}

Table 5. Producers-based commitment measurement

\begin{tabular}{|c|c|c|c|}
\hline & & Relationship Importance & $\begin{array}{l}\text { Authors having retained these } \\
\text { items }\end{array}$ \\
\hline$>$ & Eng 1 & $\begin{array}{l}\text { Speaking about customers' commitment } \\
\text { We pay a great attention to the relationship with } \\
\text { this customer. }\end{array}$ & $\begin{array}{ll}\bullet & \text { Morgan and Hunt } \\
\text { (1994) } & \\
\bullet & \text { Myriam Manzano }\end{array}$ \\
\hline$>$ & Eng 2 & $\begin{array}{l}>\text { We are very much involved in the relationship with } \\
\text { this customer. } \\
>\quad \text { These customers maintain their commitments. }\end{array}$ & Anderson and Weitz \\
\hline$>$ & $\begin{array}{l}\text { Eng } 4 \\
\text { Eng } 5 \\
\text { Eng } 6\end{array}$ & $\begin{array}{l}\text { The relationship we have with this customer is a } \\
\text { relationship that we wish to keep as long as possible. } \\
\text { We consider our relationship as an alliance. } \\
\text { Our relationship with this customer is durable. }\end{array}$ & $\begin{array}{l}\text { Kumar et al. (1995). } \\
\text { Lusch and Brown }\end{array}$ \\
\hline
\end{tabular}


Table 6. Producers perceptions

\begin{tabular}{|c|c|c|c|c|}
\hline $\begin{array}{c}\text { Independent } \\
\text { variables }\end{array}$ & Dependent variable & T-student & $\begin{array}{c}\text { Significance } \\
\text { T test }\end{array}$ & Hypotheses testing \\
\hline Dependence & $\begin{array}{c}\text { Negotiation } \\
\text { conduct }\end{array}$ & 2,180 & Significant & Validated \\
\hline Commitment & $\begin{array}{c}\text { Negotiation } \\
\text { conduct }\end{array}$ & 5.308 & Significant & Validated \\
\hline
\end{tabular}

Table 7. The impact of dependence on integrative negotiation conduct

\begin{tabular}{|c|c|c|c|c|c|}
\hline \multirow{2}{*}{$\begin{array}{l}\text { Independent } \\
\text { variable }\end{array}$} & \multirow{2}{*}{$\begin{array}{l}\text { Non-standardized } \\
\text { regression } \\
\text { coefficients }(\mathrm{B})\end{array}$} & \multirow{2}{*}{$\begin{array}{c}\text { Standard } \\
\text { Error }\end{array}$} & \multicolumn{2}{|c|}{ Significance } & \multirow{2}{*}{$\begin{array}{c}\text { Simple } \\
\text { correlation } \\
\text { coefficient }\end{array}$} \\
\hline & & & student Test & t test & \\
\hline Constant & 0.414 & 1.751 & 0.236 & 0.814 & \\
\hline Dpendence & 0.351 & 0,120 & 2,934 & $(0,004)^{*}$ & 0,551 \\
\hline Commitment & 0.401 & 0.369 & 3.426 & $(0.001)^{*}$ & 0.694 \\
\hline
\end{tabular}

$*$ indicates significance at $5 \%$ level 